\title{
Main Characters' Personality in Gita Savitri Devi's Rentang Kisah and Andori Andriani's Doriyaki
}

\author{
Oktaviana Araminta Putriyanti ${ }^{1}$, Retno Winarni ${ }^{2}$, and Muhammad Rohmadi ${ }^{3}$ \\ \{oktavianaputri@student.uns.ac.id ${ }^{1}$,winarniuns@yahoo.com²,mamad_r76@staff.uns.ac.id ${ }^{3}$ \} \\ 1,2,3 Indonesia Language Education Program, Faculty of Postgraduate,Universitas Sebelas \\ Maret, Indonesia
}

\begin{abstract}
Literature work, particularly novel, is closely related to social life. Social life itself has a tight bonding with someone's personality. Gita is the main character of Rentang Kisah novel, while Dori is the main character of Doriyaki novel. The life of Gita and Dori is quite complicated like a roller coaster. Gita and Dori are presented as teenager who is appropriate as a role model because of their persistence in achieving their dream to educate themselves abroad. The family conflict and mental flaming of both characters make this novel interesting to define more deeply. Both Gita's and Dori's personality are reflection for people to make them more concern to the people nearby. This research is descriptive qualitative research. The data is collected by investing the quotation of both Gita and Dori who have the personality aspect of Carl Gustav Jung. The purpose of the research is to figure out the personality of the main character in Rentang Kisah and Doriyaki novel according to the personality theory of Carl Gustav Jung. The result of this research is that Gita and Dori have the personality aspect which refers to the personality theory of Carl Gustav Jung, ego; personal subconscious; collective subconscious.
\end{abstract}

Keywords: main character's personality, novel

\section{INTRODUCTION}

Literature work is a picture of someone's life in a certain people. The literature psychological is the review of literature work which has process and psychological activities on human inside[1]. The literature psychological is used to identify the character's personality on literature work. Personality is part of someone's soul which becomes a unity[2]. Personality in someone is not divided on its function. The literature psychological is the understanding of the character's psychological aspect in literature work[3].

Psychology and literature has a relation. The relation between literature work and psychology is literature as a psychological symptom which displays the psychological aspect through the character[4]. Rentang Kisah and Doriyaki novel are best seller novels. The novel which tells us about the personal life of each character as well as the conflicts occurred in their life put the novel on readers' heart. Moreover, both of the characters are an influencer who is adored by millennial. 
The research of the character's personality in this novel which described the personal experience and occurred in reality has not been conducted yet. The mostly character researches conducted by many researchers are the research of novels with many imaginations inside. The common research conducted is by using the theory of Sigmund Freud (i.e identity, ego, super ego). The researcher used the character theory of Carl Gustav Jung because (ego, personal subconscious, collective subconscious) are a unity possessed by every person.

The character theory of Carl Jung consists of the components of people character; they are ego; personal subconscious and collective subconscious. Ego is part of someone's psychology consisting of consciousness on people. Ego is someone's self-consciousness centered to think, feel and remember[5]. Ego is a consciousness on an individual. Ego acts as an individual guideline to run the functions based on the reality principle[6]. Ego is different among individuals depend on each self-consciousness.

Personal subconscious contains something which is realized in subconscious. Personal subconscious consists of materials which are prior realized then forgotten[5]. Personal unconsciousness is somethings got by an individual during their life. Personal subconscious is something recessive, forgotten and thought under consciousness[7]. Personal subconscious appears when someone is on unwanted circumstance. Another relevant study was done by Tuti Apriani with the title "Self Integrity Of The Main Character in The Movie The Ron Clark Story By Randa Haines (A Study of Psychoanalysis Theory). The result of this research show that Ron Clark is a main character who has self-integrity because the personal consciousness and collective consciousness dominate more than his consciousness or ego[8].

Collective subconscious is part of everyone's psychology which has similar consciousness. Collective subconscious reflects collective experience owned by people in the past[5]. Collective subconscious contains a feeling among individuals who have biological relationship. It is correlated with the research conducted by Tri Septriani and Renni Handayani entitled "Kepribadian Tokoh dalam Novel Mencari Perempuan yang Hilang (Psychoanalysis review of Carl Gustav Jung). The result of research shows that there is a level of personal consciousness and collective unconsciousness of characters in novel[9].

The relevant research to this research is the research conducted by Alfian Rokhmansyah entitled "Struktur Kepribadian Tokoh Utama dalam Novel The Sweet Sins Karya Rangga Wirianto". The result of the research was found that the main character has consciousness and unconsciousness personality[10]. Another relevant research is conducted by Nur Intan Fatmawati entitled an artist's personality and young girl in the short story of Wajh AlHaqiqah". The analysis result shows that every character has different personality. The structure of people soul is encouraged from both conscious and subconscious[11].

Another relevant research is conducted by Renni Handayani Sembiring, Herlina and Siti Gomo Attas. The research is entitled "The Personality of Main Character in the Negeri Para Bedebah Novel by Tere Liye, Psychoanalysis Review of Carl Gustav Jung”. The result of this research shows that there is a personality of main character [12]. The relevant research is conducted by Alfian Rokhmansyah and Ratna Asmarani. This research entitled "Structure of Collective Unconsciousness of Them Main Character in The Sweet Sins Novel by Rangga Wirianto Putra". The result of this research Rei's unconsciousness structure influences conflicts has occurred whether in him self or with the other characters[13].

Relevant research is conducted by Nuriman Nurfitriani dan Emzir with the title "The Personality of Main Character in The Film Series Nobuta Wo Produce by Izumi Kizara (Carl gustav jung Psychonalytic Approach)". The result showed that Kiritani Shuuji as the main character of film series: Nobuta wo Produce by Izumi Kizara has two tendencies of the dominant personality type, thinking introvert type and feeling ekstravert type. It shows that the 
theory of Carl Jung's Gutav personality is not only used to analyze the personality of the characters in the novel, but can also be used to analyze the personality of the characters in the film[14].

\section{METHOD}

This research is descriptive qualitative research with the data of paragraph in Rentang Kisah and Doriyaki novel. The method used is literature method which is collecting the data by reading book and relevant article to this research. The source of the data used is Rentang Kisah and Doriyaki novel as well as the books refer to the research. The sampling technique used is purposive sampling. The technique of data collecting used 2 techniques, reading and taking a note. The triangulation used in this research is data and theory triangulation. The technique of data anaylsis is analysing the content by using the literature psychological approach of Carl Gustav Jung personal theory.

\section{RESULT AND DISCUSSION}

A story in a novel must have several characters both main and default character. Every character must have their own personality. The novel of Rentang Kisah and Dorayaki are two of several novels which strongly describe the personality of the main characters. Rentang Kisah novel has the main character named Gita, while Doriyaki has the main character named Dori. The personality of both the main characters will be analyzed by using the personality theory of Carl Gustav Jung, ego; personal subconscious; and collective subconscious. The personality of both main characters will be compared to find out whether there is similarity or difference of each character. Belows are the classification of personality aspect owned by the main character in Rentang Kisah novel by Gita Savitri Devi and Doriyaki by Andori Andriani.

\subsection{Gita's Ego in the Rentang Kisah novel}

The aspect of ego in Gita character has appeared since Gita's teenager. Gita did not feel to have a mother figure like her friends. Gita always thought that mother is a creepy figure. Sooner, mother has become someone who was Gita afraid of not respected. It could be seen in this quotation below.

"I quite remembered how her figure in my eyes was. Mommy was just someone who likes to scold. Whatever I did, I was always wrong. I wasn't good enough for her and just made her angry. So, it's no wonder if we were in quarrel. Actually, I wanted to revenge mommy's anger with my anger but I was too afraid. Moomy was so creepy when she was angry." (page 3)

The quotation shows that there was a time when Gita wanted to revenge her mother's anger. Gita always seems wrong in her mother's eyes. The little thing she did, she must be wrong and Gita takes her mother as a creepy figure.

Continuing study to the university with desired program is every teenager's dream including Gita. When she decided the program for study, Gita was faced with her mother's disagreement. Gita's ego is too high when she wants to take her desired program. It could be seen in this quotation.

"Facing the truth that Mom quite disagreed with my choice makes me at the end way. I've been accepted in the program I wanted, I was really interested for. Truthfully, I just could be sure with my own choice and not listen to my mom's desire." (page 34). 
The quotation shows Gita's ego to continue her study and take the program as her willing and interest. Gita wants to take the program she really wants to choose not her mother. Gita thinks that she will run for her life so she can choose every program she will take in the university.

\subsection{Gita's Personal Subconscious in Rentang Kisah novel}

The mother's anger to Gita is just for Gita's goodness. Gita realized that what her mother did must be good although Gita felt it just something common. It could be seen from this quotation below.

"What mom said was quite true. Mommy always warns my habit to watch TV too close or read book while lay down could make my eyes got myopic. I rarely care about it till one day my sight was getting worse. However, I was afraid to tell Mommy. I've already imagined her scolding." (Page 5)

The quotation seemed that Gita's personal subconscious realized that what her mother told was correct. Although Gita thought her mother was too fussy but everything is for her goodness. It could be seen when Gita felt there was something wrong with her eyesight and she was afraid to tell her mother. Her eyesight became worse and finally Gita dare herself to tell her mother about her eyesight.

Gita grew up to be a temperamental teenager. Moreover she knew that she had to postpone her departure to Germany, seeing her friends had gone to college and she hasn't yet. After ruminating herself, Gita realized that she had to accept everything happened in her life. It could be seen from this quotation below.

"After ruminating what I've been through, there's no other way, I have to accept it. Rather than spending my time to be upset in this situation, I have to enjoy my year, I never know whether I still have free time when I have college in Germany. For the first time, I have learned to be sincere and have good prejudice on God's willingness. Perhaps it is the way to make me mature." (Page 49)

The quotation seemed that Gita is sincere and willing to take what has been her destiny. Her personal subconscious thought that this is the way God wants her to be. Being grateful is Gita's way to enjoy her life. Relevant research conducted by Setyorini Anjar, Wibowo Suluh Wdhi, Yulianto Ahmad the title's "La Personnalite De Candide et Les Facteurs Inconscients Qui L'influencent Dans Le Roman Candide Ou L'optimisme De Voltaire: Une Etude Psychanaltique Litteraire Selon. The results of this research show that the character Candide has a personality that is affected by all factors of unconsciousness from Carl Gustav Jung's theory, in both private and unconscious factors collective unconscious[15].

\subsection{Gita's Collective Subconscious in Rentang Kisah novel}

Collective subconscious is a feeling felt by everyone. Gita realized that her assumption about her creepy mother is totally wrong. Her mother is a care person to her. It could be seen from this quotation below.

"After suffering this illness, I suddenly become so sane. My anger and hate to mom disappear along with this illness. I've just known why my relationship with my mom did not run well. I saw my mom as an enemy not parents. Whatever my mom said and did was always wrong for me. I never show any respect. I was so scared in front of her but I always mock her at her back. There were so many lies told because I was scared to get scold. I have just realized it after I recovered." (Page 16) 
The excerpt shows that Gita is aware that all this time her mother has done the best for her. However, the mother wants the best for Gita. A mother's love for her child appears instinctively, similar to a child who has affection for his/her mother. The excerpt shows Gita's collective subconsciousness of her mother. A feeling of affection and respect should be done by a child towards his/her parents. Likewise with Gita, the love and respect that Gita gives to her mother is indeed what Gita should have done.

\subsection{Dori's ego in Doriyaki novel}

Dori's ego appears when his happy childhood disappears because of his parents' quarrel. Dori had to repeat from the bottom class because of his sudden move. Dori thought that it could happen because of his parents. It could be seen in this quotation.

"I had to repeat my third grade of primary school and I had to be downgrade to the second grade for a while. So, I was the oldest in the class. It made me hate my parents so much. I had to be downgrade and return to Indonesia and be away from my friends in Japan because of my parents' problems." (Page 36)

The quotation shows Dori's upset feeling because he had to leave everything he got in Japanese. His life changed because of his parents problems. Dori felt so disappointed with his parents' behavior. The analysis by using the theory of psychoanalysis on the main character of the novel has also been researched by Ruswandi, the title's "Study of Psychoanalysis of the main character in the Novel Women at Point Zero/zero point women in the works of Nawal El Sadawi ". The results of the study showed that the main character experiencing various problems berkiatan with the psychoanalysis of his life. The problems experienced by the main character's life is affected by the condition of the economy of the family. It is the same as that experienced by a character that has a family problem Dori[16]

The family problems experienced by Dori put him in pressure. Illness has come to change his body. Dori is so pessimistic with his life which is different from his friends. The quotation shows that Dori lives in his unwanted life. Dori's ego appears to end his life. His ego is success to influence his mind. If Dori dies, he does not need to be involved in his parents' problems.

\subsection{Dori's Ego Personal Subconscious in Doriyaki Novel}

Dori wants to have a life like his friends have, being happy with his family. Looking cheerful and having no problems are Dori's ways to cover his heart destruction. It could be seen in this quotation below.

"None of my friends at school know my problems. Every day, I've tried to be cheerful as I can, showing that I'm fine. Nobody realizes something happened in my family and I am also ashamed if they know the true I am." (Page 28).

This quotation shows that Dori wants to be looked normal, behave like his friends in harmonious family. Dori's personal subconscious wants to show that he can be so cheerful at school although he does not have a happy family like his friends imagine. The quotation shows that something Dori did is wrong. The personal subconscious is conscious. Dori should not behave like that. Doni thinks that he must change. If he keeps doing the same, he will be the same as his parents. Relevant research conducted by Kusuma Yanny Husain with the title "Ketidaksadaran dan Faktor yang Mempengaruhi Struktur Ketidaksadaran Tokoh Utama (Aku) Novel Napas Mayat Karya Bagus Dwi Hananto: Kajian Psikologi Analitis Carl Gustav 
Jung. The results showed that the figures I have a personality that is the personal unconscious and the collective unconscious[17].

\subsection{Dori's ego Collective Subconscious in Doriyaki novel}

Dori's collective subconscious is seemed to his father. How hard his father is, he must love and respect his father. Moreover, collective subconscious owned by everyone is conscious feeling from the people itself with the closer person.

"Dad.. no dad. You still have Andri who loves you, you still have Tasha..," ask me while hugging my daddy tightly. (Page 39)

The quotation shows the collective subconscious of a child who love the parents. Father is someone who Dori loves so much. It is a collective subconscious feeling of a child to his father. The quotation shows that Dori realizes his father is someone who cares about him. Dori wants to reply all the attention given by his father. Dori wants to do something he never did before. It appears in Dori's collective subconscious as a son. Dori must be able to make his father happy. Simple and little things he did are truly meaningful for his father.

The personality of Gita and Dori is absolute personality in every indidvidual. The capacity of every personality is not the same but everyone must have the personality. Carl Gustav Jung as an analytical psychologist assumes that personality is dynamic. A healthy and strong personality will result on optimally developed personality[18]. This research analyzes the personality of a character of which the story is taken from the character's life. A lot of previous researches just focus or find the personality in one level consciousness, collective subconscious [19]. In this research, the researcher focuses on conducting research the three aspects of human's personality starting from ego, personal subconscious and collective subconscious where the three personalities have the own level.

\section{CONCLUSION}

According to the data analysis conducted, there is personality aspect refers to the Carl Gustav Jung's theory to Gita character in Rentang Kisah novel and Dori character in Doriyaki novel. The Ego in Gita is described as a temperamental figure and she must get everything she wants to have as she expects. Gita's personal subconscious appears when Gita wants to continue her study. The overcome she passed before continuing her study to Germany starting from her argue with her mother, her disappointment because her postponed departure to Germany until her collective subconscious appears. The pain she felt to the attention given by her mother makes her realized that her mother is a figure she must love and respect. Gita realized that she could not succeed without her mother's dua and blessing.

Dori's ego has appeared since Dori's childhood when Dori was faced to his family problems. Dori's ego flared up when he felt that the happiness he should get and feel went disappear because of his parents quarrel. Thinking to die is Dori's way to avoid the problems in his life. However, Dori's personal subconscious realized that he cannot put himself in sorrow. His parents' divorce should have not made his life messy and useless. Dori must be able to prove to his mother that he can be a good and independent son. Dori can prove that he can continue his study to Japan as his dream. Gradually, Dori's collective subconscious realized that he has to make a peace with his parents. Dori has to love his parents. Giving a simple attention like surprise and gift on the birthday are kinds of his attention and affection to his parents. 
The research of character's personality using the theory of Carl Gustav Jung is one of the alternatives because many researchers use the psychoanalysis theory of Sigmund Freud. The theory of Carl Jung is simpler and easily to implement because it related to ego, personal subconscious and collective subconscious. The theory of Carl Jung can also be implemented in psychology field because the level of personality on human starting from ego, personal subconscious and collective subconscious. The implementation of Carl Jung theory is also in the novel of which the characters experienced personality level on human.

\section{REFERENCE}

[1] Minderop, Psikologi Sastra. Jakarta: Yayasan Pustaka Obor Indonesia, 2013.

[2] I. Abraham, "Struktur kepribadian tokoh dalam novel Surat Kecil untuk Tuhan karya Agnes Davonar," Kembara, vol. 3, no. 1, pp. 55-63, 2017.

[3] N. K. Ratna, Sastra dan Cultural Studies: Respresentasi Fiksi dan Fakta. Yogyakarta: Pustaka Pelajar, 2005.

[4] L. Suprapto And B. Waluyo, "Kajian Psikologi Sastra Dan Nilai Karakter Novel 9 Dari Nadira Karya Leila S. Chudori," 2014.

[5] B. R. Olson, Matthew. H, Dan Hergenhahn, Pengantar Teori-Teori Kepribadian. Yogyakarta: Pustaka Pelajar, 2013.

[6] S. Endraswara, Metodologi Penelitian Sastra. Yogyakarta: Caps, 2018.

[7] A. Rokhmansyah, Studi Dan Pengkajian Sastra:Perkenalan Awal Terhadap Ilmu. Yogyakarta: Graha Ilmu, 2014.

[8] T. Apriani, "Self-Integrity Of The Main Character In The Movie The Ron Clark Story By Randa Haines (A Study Of Psychoanalysis Theory)," Bahtera J. Pendidik. Bhs. Dan Sastra, Vol. 18, No. 1, Pp. 33-46, 2019.

[9] T. Septiarini and R. H. Sembiring, "Kepribadian Tokoh Dalam Novel Mencari Perempuan Yang Hilang (Kajian Psikoanalisis Carl Gustav Jung)," Ling. J. Ilmu Bhs. dan Sastra, vol. 12, no. 2, pp. 79-89, 2017.

[10] A. Rokhmansyah, "Struktur Kepribadian Tokoh Utama dalam Novel The Sweet Sins Karya Rangga Wirianto Putra," Deiksis J. Pendidik. Bhs. dan Sastra Indones., vol. 5, no. 2, p. 25, 2018.

[11] N. I. Fatmawati, E. P. Indriyani, and E. Farhah, "KEPRIBADIAN TOKOH SENIMAN DAN Gadis Muda Dalam Cerpen Wajh Al-Haqiqāh," Haluan Sastra Budaya, Vol. 1, No. 2, Pp. 172-184, 2017.

[12] R. H. Sembiring, H. Herlina, And S. G. Attas, "Kepribadian Tokoh Utama Dalam Novel Negeri Para Bedebah Karya Tere Liye Kajian Psikoanalisis Carl Gustav Jung," Transform. J. Bahasa, Sastra, Dan Pengajarannya, Vol. 2, No. 2, Pp. 157-172, 2018.

[13] A. Rokhmansyah And R. Asmarani, "Struktur Ketaksadaran Kolektif Tokoh Utama Dalam Novel The Sweet Sins Karya Rangga Wirianto Putra," Aksara, Vol. 30, No. 2, Pp. 221-236, 2018.

[14] N. Nuriman And E. Emzir, "The Personality Of Main Character In The Film Series Nobuta Wo Produce By Izumi Kizara (A Carl Gustav Jung's Psychoanalytic Approach)," Ijlecr-International J. Lang. Educ. Cult. Rev., Vol. 4, No. 1, Pp. 58-67, 2018.

[15] A. Setyorini, "La Personnalite De Candide Et Les Facteurs Inconscients Qui L'influencent Dans Le Roman Candide Ou L'optimisme De Voltaire: Une Étude Psychanalytique Litteraire Selon," J. Ling. Litteratia, Vol. 2, No. 2, 2015.

[16] R. Ruswandi, "Kajian Psikoanalisis Tokoh Utama Dalam Novel Woment At Point Zero/Perempuan Di Titik Nol Karya Nawal El Sadaawi," Humanis J. Ilmu-Ilmu Sos. 
Dan Hum., Vol. 7, No. 2, Pp. 145-156, 2015.

[17] Y. Husain Kusuma, "Ketidaksadaran Dan Faktor Yang Mempengaruhi Struktur Ketidaksadaran Tokoh Utama (Aku) Novel Napas Mayat Karya Bagus Dwi Hananto: Kajian Psikologi Analitis Carl Gustav JUNG," BAPALA, vol. 4, no. 1, 2017.

[18] S. Ja'far, "Struktur Kepribadian Manusia Perspektif Psikologi dan Filsafat," Psympathic J. Ilm. Psikol., vol. 2, no. 2, pp. 209-221, 2015.

[19] K. Saddhono, "Language of Coastal Communities in the Northern Coast of Central Java: Sociolinguistic Studies in Cultural Integration Maritime-Agrarian Perspective." Adv. Sci. Let. vol. 23 no. 10 pp 10054-10056, 2017 